\title{
Fermentation of Raw Cassava Starch Using Geotrichum candidum sp. : Optimizing enzyme and starch concentrations for alcohol production
}

\author{
S.N.T. DE SILVA, A.J.A. TILAKARATNA, M.M.W.K.B. MANCHANAYAKE and D.P.S.T.G. \\ ATTANAYAKA \\ Department of Biotechnology, Faculty of Agriculture and Plantation Management, Wayamba University \\ of Sri Lanka
}

\begin{abstract}
Production of bioethanol is a global requirement to address the question of energy crisis. Attempts have been made to use agricultural starch based renewable resources to produce ethanol. Starchy materials should be converted into simpler sugars prior to fermentation and this is achieved by treating with enzymes. Fermentation medium containing $1.5 \mathrm{~g}, 3 \mathrm{~g}$ and $10 \mathrm{~g}$ of raw cassava were optimized for brix value by directly inoculating samples (DIS) with fungi $G$. candidum or treating the medium with different concentrations of crude enzyme $(50 \mathrm{~mL} \& 100 \mathrm{~mL})$ and $50 \%$ ammonium sulphate fractionated proteins (Enzyme Treated Samples -ETS). Highest brix values containing samples for $1.5 \mathrm{~g}, 3 \mathrm{~g}$ and $10 \mathrm{~g}$ of cassava under two different experimental conditions were ETS1, ETS2, ETS3, and DIS1, DIS2, DIS3 respectively. The samples were fermented with yeast stock cultures of maximum viable cells $\left(7.065 \times 10^{6}\right.$ cells $\mathrm{cm}^{-3}$ \&86.4\% viability). Brix value and alcohol percentage for these six samples showed that $\mathbf{5 0 \%}$ Ammonium sulphate saturated enzyme samples is suitable to obtain higher brix value when compared to crude and direct inoculation method. Then the culture conditions were optimized for starch percentage, $\mathrm{pH}$ and viable cell numbers. The results showed that an effective increase in Brix value of 2.3 could be obtained with $3 \%$ and $4 \%$ starch after 12 hrs incubation period when treated with $50 \%$ ammonium sulphate fractionated enzyme. Optimized fermentation conditions showed that the viable cell numbers of culture medium decreased during 36-48 hrs of incubation period. There was a sudden $\mathrm{pH}$ drop after $12 \mathrm{hrs}$ and considerable changes were not observable in prolonged incubation. Optimization results for alcohol with $4 \%$ starch showed that a high percentage of alcohol $(2.5 \%)$ could be obtained after 60 hrs incubation. In conclusion, $\mathbf{5 0} \%$ saturated enzyme sample at room temperature and $4 \%$ starch has yielded highest brix value and resulted $2.5 \%$ of alcohol in $100 \mathrm{~mL}$ of fermentation medium.
\end{abstract}

KEYWORDS: Alcohol, raw starch, a-amylase

\section{INTRODUCTION}

The use of bioethanol as an alternative source of fuel has raised considerable interest recently due to environmental problems and high petroleum prices [1]. Ethanol has the advantages of being renewable, provide cleaner burning and produce no green-house gases compared to conventional fossil fuel [2]. One of the most common methods of bioethanol production is fermentation of renewable biomass, such as starch, by yeast Saccharomyces cerevisiae[1]. Bioethanol production by yeast consists of three major processes. At the first step starchy materials are obtained from agricultural crops. During the second step, these starchy materials are converted into fermentable sugars by enzymatic degradation or by acid hydrolysis. These simple sugars are then fermented to produce ethanol by yeast. At the final step ethanol will be recovered from the fermentation broth by distillation. The most critical step in the overall process is bioconversion of starchy materials to ethanol. This is because Saccharomyces cerevisiae, one of the best microorganisms for producing ethanol, is inefficient in utilizing starchy materials directly. One of the common straightforward approaches to get over this problem is to add $\alpha$-amylase and glucoamylase exogenously to convert starchy materials to glucose [3]. Major starchy substrates for bioethanol production are wheat, rice, potato and corn [4]. Cassava starch is also one of the richest fermentable substances for the production of alcohol. The approximate composition of cassava starch on dry weight basis was $0.24 \%$ ash, $0.13 \%$ fat, $0.49 \%$ protein, $0.15 \%$ crude fiber and $98.4 \% \operatorname{starch}[5]$. Starch availability and its processing cost are the main considerations in the overall production cost of sugars from starchy substrates. Only few microorganisms have been reported to possess the ability to produce raw starch degrading $\alpha$-amylase to date [6]-[7].

Previously, we have isolated and characterized a soil born fungi Geotrichumcandidumspecies. This fungus has the ability to act upon raw cassava starch and produce fermentable sugars [8]. In this study the culture conditions were tested to evaluate the effectiveness of crude enzyme and partially purified enzymes for their ability to digest raw starch. Moreover, different concentrations of raw starch content $(w / v)$ in the 
fermentation medium treated with enzyme was optimized for highest brix value in order to produce alcohol by fermentation.

\section{MATERIALS AND METHODS}

\section{Preparation of Raw Starch Flour from Cassava}

Raw starch was prepared from cassava, modifying the method described by Janszet al, (1976) [9]. Cassava tubers were washed and the rind was removed. This was sliced in to thin chips by hand and dried at oven at $110^{\circ} \mathrm{C}$ for $24 \mathrm{hrs}$. These chips were then soaked in 2 liters of distilled water for eight hours, drained it off and re-dried in an oven at $110^{\circ} \mathrm{C}$ for 24 hrs. Dried chips were ground firmly, sieved and used as raw cassava starch during the study.

\section{Media preparation, Inoculation and Culture Maintenances}

Soil born fungi G.candidumspecies was grown in a Erlenmeyer flasks containing $50 \mathrm{ml}$ sterilized fermentation medium (1.5\%soluble starch, $0.2 \%$ yeast extract, $0.01 \%$ $\mathrm{MgSO}_{4}, 0.01 \% \mathrm{CaCl}_{2}, 0.26 \% \mathrm{KH}_{2} \mathrm{PO}_{4}, \mathrm{pH} 4.0$ ) at $32^{\circ} \mathrm{C}$ in a rotary shaker at $100 \mathrm{rpm}$ for $72 \mathrm{hrs}$. [7]. Pure cultures were maintained throughout the research period on PDA slants at $4^{\circ} \mathrm{C}$ and sub culturing was done at two weeks interval.

\section{Crude enzyme preparation}

Crude enzyme was prepared in a fermentation medium comprised of $0.2 \%$ yeast extract, $0.01 \% \mathrm{MgSO}_{4}, 0.01 \% \mathrm{CaCl}_{2}$ \& $0.26 \% \mathrm{KH}_{2} \mathrm{PO}_{4}$ in $1 \mathrm{~L}$ was autoclaved for $15 \mathrm{~min}$ at $121^{\circ} \mathrm{C}$ (pH 4.0) [7]. To $100 \mathrm{~mL}$ of the fermentation medium, $1.5 \mathrm{~g}$ of raw cassava was added and inoculated with three profuse agar plugs of $8 \mathrm{~mm}$ in diameter from G.candidum sp. Thesewere incubated for $72 \mathrm{hrs}$ at room temperature $\left(32^{\circ} \mathrm{C}\right)$ in a rotary shaker at $100 \mathrm{rpm}$. Culture supernatant recovered by centrifugation or by filtration was treated as crude enzyme.

\section{End Product Determination}

Two Erlenmeyer flasks containing $50 \mathrm{~mL}$ fermentation media were prepared with raw cassava starch $(1.5 \%$ raw cassava starch, $0.2 \%$ yeast extract, $0.01 \% \mathrm{MgSO}_{4}, 0.01 \% \mathrm{CaCl}_{2}$, $0.26 \% \mathrm{KH}_{2} \mathrm{PO}_{4}, \mathrm{pH} 4.0$ ). One of the media was directly inoculated with the fungi and samples were drawn at $12 \mathrm{hrs}$ interval. To the fermentation media of the remaining flask, crude enzyme extract was added. Samples were incubated for $7 \mathrm{hrs}$ while drawing samples at $1 \mathrm{hrs}$ interval.

Five micro litters of the direct inoculated samples and treated samples were spotted on a chromatographic paper with $1 \%$ glucose, $1 \%$ maltose as standards and end products were determined according to the method described by Chaplin and Kennedy (1986), [10].

\section{Ammonium Sulphate Fractionation of a-amylase}

Previous studies conducted on ammonium sulphate fractionation of $\alpha$-amylase indicated that $0-50 \%$ saturated precipitate contained higher $\alpha$ - amylase activity than $50-100 \%$ saturated precipitate [11]. Therefore, 50\% ammonium sulphate fractions were prepared from $100 \mathrm{~mL}$ of crude enzyme extract as described by Clowick and Kaplan (1955) [12]. Seventy two hrs old culture supernatant was immediately brought up to $50 \%$ saturation and precipitate was recovered by centrifugation. This precipitate was re-dissolved in minimum amount of $0.01 \mathrm{M}$ phosphate buffer and dialysis was done against the same buffer to remove the salts from the partially purified protein.

\section{Determination of Total Soluble Solids}

Percentage of the total soluble solids (brix value) in liquid culture was measured by hand refractometer (Atago N-1E) [13]. Measurements were taken at room temperature (RT) with temperature corrections. All the samples were centrifuged for $1 \mathrm{~min}$ at $2000 \mathrm{rpm}$ before readings were taken.

\section{Optimizing enzyme activity for maximum brix value}

The enzyme $\alpha$-amylase was produced as crude enzyme (50 $\mathrm{mL} \& 100 \mathrm{~mL}$ ) and $50 \%$ saturated form. The brix values were tested under these three conditions with $1.5 \%, 3 \%$ and $10 \%$ of raw cassava starch at RT and $37^{\circ} \mathrm{C}$. The samples were incubated for $12 \mathrm{hrs}$ and brix values were taken at $1 \mathrm{hrs}$ interval (Enzyme treated samples -ETS). Samples with maximum brix values were labeled as ETS1, ETS2 an ETS3. Similarly the conditions were optimized by directly inoculating the fungi into a fermentation medium containing raw cassava starch $(1.5 \%, 3 \%$ and $10 \%)$ (Direct Inoculation Sample - DIS) at RT and $37^{\circ} \mathrm{C}$. Maximum brix value giving 
samples were labeled as DIS1, DIS2, and DIS3. The six samples were fermented for alcohol production.

\section{Optimizing starch content for Maximum Brix value}

According to results, 50\% ammonium sulphate concentrated enzyme at RT was selected to optimize brix value for starch content. Fermentation media containing $2 \%-8 \%$ concentration of raw cassava starch were treated with the $50 \%$ saturated enzyme at RT. The cultures were agitated slowly $(50 \mathrm{rpm})$ in a rotary shaker in order to prevent the sedimentation of starch. The Brix values were taken at $12 \mathrm{hrs}$ intervals, for a period of $72 \mathrm{hrs}$.

\section{Fermentation :Preparation of Yeast pre-culture}

Five gram of sugar,dry yeast (baker's yeast) $0.5 \mathrm{~g}$ and ammonium nitrate $0.2 \mathrm{~g}$ was added into $50 \mathrm{~mL}$ of distilled water ( $\mathrm{pH} 6$ ). Initial cell number and brix value were taken. The culture was allowed for $24 \mathrm{hrs}$ incubation period at RT. Samples were drawn at $1 \mathrm{hrs}$ interval and analyzed for cell number and viability.

\section{Viability test}

One milliliter of hourly drawn yeast slurry was diluted to 10 $\mathrm{mL}$. Five drops of $0.1 \mathrm{M}$ sulfuric acid was added into diluted solution. Number of cells was counted under light microscope at $40 \times$ objective (area of the objective was measured by microscopic scale). Number of cells per milliliter was counted. The slurry was then stained with two drops of methylene blue and number of stained cells (dead cells) and unstained cells were counted (Fig 1).The equation for viability is adopted according to heamocytometer (14).

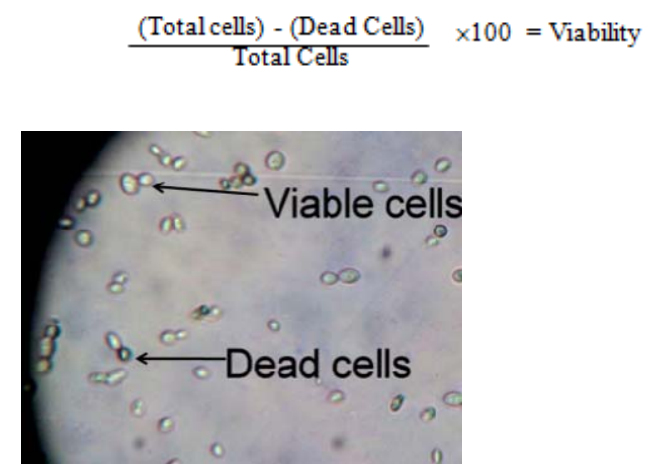

Figure 1. Yeast; Saccharomyces cerevisiaeunder light microscope $(400 \times)$

\section{Preparation of yeast stock culture}

After optimizing for cell number and viability $50 \mathrm{ml}$ of two hrs incubated slurry was transferred into $150 \mathrm{ml}$ of media. The slurry was incubated for another 2 hrs and used as the yeast stock culture with $86.4 \%$ viability and $7.065 \times 10^{6}$ cellcm $^{-3}$. The stock culture were stored at $4^{\circ} \mathrm{C}$ and used for fermentation. After enzyme hydrolysis, fermentation media containing $2 \%$ to $8 \%$ raw cassava starch were inoculated with yeast stock culture to produce alcohol. The initial $\mathrm{pH}$ was adjusted to 6. Number of live cells, dead cells and $\mathrm{pH}$ variation were measured at $12 \mathrm{hrs}$ interval for $72 \mathrm{hrs}$. At the end of incubation, the level of alcohol was measured

\section{RESULTS AND DISCUSSION}

\section{End products after hydrolysis}

End product analysis showed glucose after $1 \mathrm{hr}$ when raw starch was treated with crude enzyme (Fig 2A). Glucose could be observed after $24 \mathrm{hrs}$ when raw starch was directly inoculated with the fungi (Fig 2B). A clear observation of fungal growth was observed under the second experimental conditions indicating the utilization of initial hydrolysis products for fungal growth under direct inoculation.

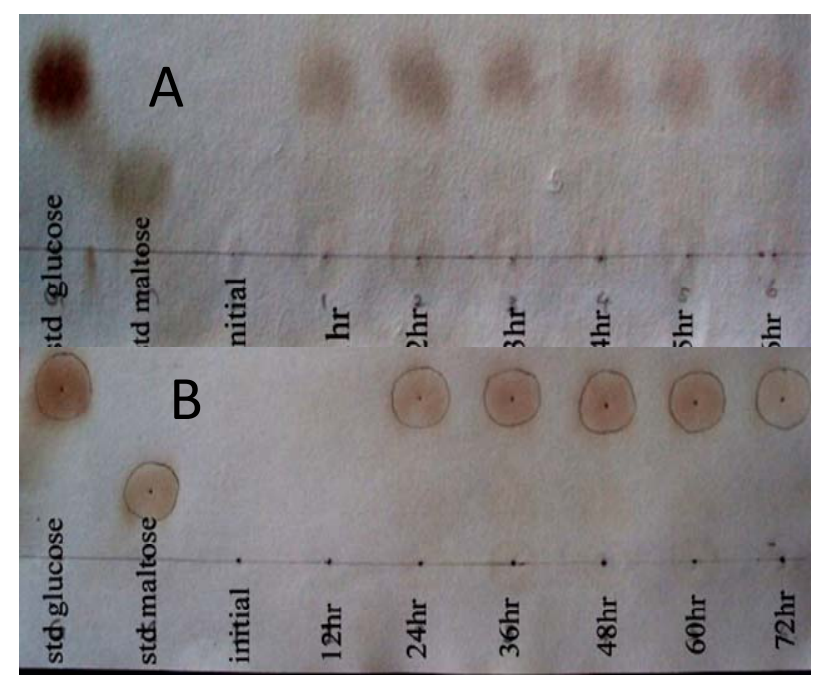

Figure 2: End product analysis: A; enzyme treated samples at $1 \mathrm{hrs}$ interval, $\mathrm{B}$; direct inoculated samples at $12 \mathrm{hrs}$ intervals.

\section{Brix value optimization}

Insoluble materials were precipitated by centrifugation to measure the brix value. The maximum brix value of 1.2 was 
obtained for $1.5 \%$ raw cassava when treated with $50 \%$ ammonium sulphatefractionated enzyme after $7 \mathrm{hrs}$ at RT (ETS1) (Table 1) The maximum brix value of 1.4 was obtained for $3 \%$ of raw cassava when digested with $50 \%$ ammonium sulphate fractionated enzyme after $3 \mathrm{hrs}$ at RT (EST2). For $10 \%$ of raw cassava, the maximum brix value of 2 obtained when it was digested with $50 \%$ ammonium sulphate fractionated enzyme after $3 \mathrm{hrs}$ at RT (EST3) (Table 1). The direct inoculation of fungi into FM containing $1.5 \mathrm{~g}$ of cassava (DIS1) showed no change in brix value even after 72 hrs inoculation (Table 2).

Under direct inoculation method, fermentation medium containing $1.5 \%$ cassava showed no change in brix value even after $72 \mathrm{hrs}$ incubation period. Three percent and $10 \%$ of cassava under this method showed a brix value of 1 and 1.9 respectively after $36 \mathrm{hrs}$ inoculation (DIS2 \& DIS3) (Table 2).

In addition, $\mathrm{pH}$ value of the DIS samples was gradually decreased from $\mathrm{pH} 4$ to $\mathrm{pH} 3$ (data not shown). These results indicate that $50 \%$ ammonium sulphate saturated enzyme has highest activity at RT when compared to crude enzyme extraction and direct inoculation method

\section{Optimizing Culture Conditions for Maximum Brix Value}

\section{Optimizing brix value with starch}

The maximum Brix value of 2.3 was obtained for $3 \%, 4 \%, 5$ $\%, 6 \%, 7 \%$, and $8 \%$ of cassava digested with $50 \%$ ammonium sulphate fractionated enzyme after $12 \mathrm{hrs}$ at RT. The samples with $3 \%$ and $4 \%$ starch showed the most effective increase of Brix value after $12 \mathrm{hrs}$ period rising from 1.8 to 2.3 . However the effectiveness of the enzyme on starch was considerably low and the parameters needed to be optimized by changing $\mathrm{pH}$, temperature with different ammonium sulphate fractionations of the enzyme under cold conditions to retain maximum enzyme activity.

Table 1: Changes in Brix value at different concentrations of starch with enzyme treated method (ETS)

\begin{tabular}{|c|c|c|c|c|c|c|c|c|c|c|c|c|c|c|c|c|c|c|}
\hline Test & \multicolumn{6}{|c|}{ Test -1} & \multicolumn{6}{|c|}{ Test-2 } & \multicolumn{6}{|c|}{ Test-3 } \\
\hline & \multicolumn{18}{|c|}{ Brix value } \\
\hline Starch & \multicolumn{2}{|c|}{$1.5 \%$} & \multicolumn{2}{|c|}{$3 \%$} & \multicolumn{2}{|c|}{$10 \%$} & \multicolumn{2}{|c|}{$1.5 \%$} & \multicolumn{2}{|c|}{$3 \%$} & \multicolumn{2}{|c|}{$10 \%$} & \multicolumn{2}{|c|}{$1.5 \%$} & \multicolumn{2}{|c|}{$3 \%$} & \multicolumn{2}{|c|}{$10 \%$} \\
\hline $\begin{array}{l}\text { Time } \\
\text { Hrs }\end{array}$ & RT & $37^{\circ} \mathrm{C}$ & RT & $37^{\circ} \mathrm{C}$ & RT & $37^{\circ} \mathrm{C}$ & RT & $37^{\circ} \mathrm{C}$ & RT & $37^{\circ} \mathrm{C}$ & RT & $37^{\circ} \mathrm{C}$ & RT & $37^{\circ} \mathrm{C}$ & RT & $37^{\circ} \mathrm{C}$ & RT & $37^{\circ} \mathrm{C}$ \\
\hline Initial & 0.8 & 0.8 & 0.8 & 0.8 & 1.1 & 1.1 & 1 & 1 & 1.1 & 1.1 & 1.4 & 1.4 & 1 & 1 & 1.1 & 1.1 & 1.4 & 1.4 \\
\hline 1 & 0.8 & 0.8 & 0.8 & 0.8 & 1.1 & 1.1 & 1 & 1 & 1.2 & 1.1 & 1.4 & 1.4 & 1 & 1 & 1.2 & 1.2 & 1.6 & 1.6 \\
\hline 2 & 0.8 & 0.6 & 0.8 & 0.8 & 1.1 & 1.1 & 1 & 1 & 1.1 & 1.1 & 1.2 & 1.2 & 1 & 1 & 1.3 & 1.3 & 1.8 & 1.7 \\
\hline 3 & 0.9 & 0.9 & 0.8 & 0.7 & 1.1 & 1.1 & 1.1 & 1.1 & 1.1 & 1.1 & 1.0 & 1.1 & 1 & 1 & 1.4 & 1.3 & 2.0 & 1.9 \\
\hline 4 & 0.8 & 0.9 & 0.9 & 0.7 & 1.2 & 1.1 & 1.1 & 1.1 & 1.1 & 1.1 & 1.1 & 1.1 & 1 & 1 & 1.4 & 1.3 & 2.0 & 1.8 \\
\hline 5 & 0.9 & 1 & 0.9 & 0.8 & 1.1 & 1.1 & 1.1 & 1.1 & 1.0 & 1.1 & 1.3 & 1.3 & 1 & 1.1 & 1.4 & 1.4 & 2.0 & 1.9 \\
\hline 6 & 0.9 & 1 & 0.8 & 0.8 & 1.1 & 1.3 & 1.1 & 1.1 & 1.0 & 1.1 & 1.6 & 1.6 & 1 & 1.1 & 1.3 & 1.3 & 2.0 & 1.9 \\
\hline 7 & 0.9 & 1 & 0.9 & 0.8 & 1.2 & 1.2 & 1.2 & 1.1 & 1 & 1 & 2 & 1.4 & 1 & 1.1 & 1.4 & 1.3 & 1.9 & 2.0 \\
\hline 12 & 0.9 & 1 & 0.9 & 0.8 & 1.2 & 1.2 & 1.1 & 1 & 1 & 1.1 & 2 & 1.4 & 1 & 1.1 & 1.4 & 1.3 & 2.0 & 2.0 \\
\hline
\end{tabular}

Test $1,50 \mathrm{~mL}$ crude enzyme extract, Test-2, $100 \mathrm{~mL}$ crude enzyme extract, Test $-3,50 \%\left(\mathrm{NH}_{4}\right)_{2} \mathrm{SO}_{4}$ fraction,

RT -Room Temperature

Table 2 : Changes in Brix value for different starch concentrations with direct inoculation method (DIS)

\begin{tabular}{|c|c|c|c|c|c|c|}
\hline \multirow{2}{*}{ Starch } & \multicolumn{2}{|c|}{$1.5 \%$} & \multicolumn{2}{|c|}{$3 \%$} & \multicolumn{2}{|c|}{$10 \%$} \\
\hline & \multicolumn{6}{|c|}{ Brix value } \\
\hline Time (hrs) & RT & $37^{\circ} \mathrm{C}$ & RT & $37^{\circ} \mathrm{C}$ & RT & $37^{\circ} \mathrm{C}$ \\
\hline Initial & 0.8 & 0.8 & 0.9 & 0.9 & 1.4 & 1.4 \\
\hline 12 & 0.8 & 0.8 & 0.9 & 0.9 & 1.4 & 1.4 \\
\hline 24 & 0.8 & 0.8 & 0.9 & 0.9 & 1.7 & 1.4 \\
\hline 36 & 0.8 & 0.8 & 1 & 0.9 & 1.9 & 1.6 \\
\hline 48 & 0.8 & 0.8 & 1 & 0.9 & 2 & 1.8 \\
\hline 60 & 0.8 & 0.8 & 1 & 0.9 & 2 & 1.8 \\
\hline 72 & 0.8 & 0.8 & 1 & 0.9 & 2 & 1.4 \\
\hline
\end{tabular}

RT-Room temperature 


\section{Optimizing Culture Conditions for Maximum Alcohol Production}

In all samples number of live yeast cells increased gradually during the initial incubation period and started to reduce in prolonged incubation. Samples with $3 \%, 4 \%, 5 \%, 7 \%$, and $8 \%$ starch showed that there is an increase in live yeast cells up to $36 \mathrm{hrs}$ (Fig 3). The sample with $2 \%$ and $6 \%$ starch showed the highest number of cells after $48 \mathrm{hrs}$ and $24 \mathrm{hrs}$ period of incubation. Maximum number of live yeast cells was $9.66 \times 10^{6} \mathrm{~cm}^{-3}$ at $36 \mathrm{hrs}$ for $3 \%$ cassava. In addition, during fermentation period there was no clear variation of dead yeast cells. The samples with $2 \%, 3 \%, 4 \%$, and $6 \%$ cassava indicated that the number of dead cells increased at $48 \mathrm{hrs}$ whereas it was observed after $60 \mathrm{hrs}$ in $5 \%$ and $7 \%$ samples. A sharp $\mathrm{pH}$ drop was observed during the initial time point of 12 hrs. However the subsequent changes were not significant. This may be due to multiplication of yeast cells during initial stages. The final alcohol percentages of samples containing $2 \%$ to $8 \%$ cassava after $72 \mathrm{hrs}$ incubation period were $3.07 \%, 3.32 \%, 4.07 \%, 3.44 \%, 3.32 \%, 3.26 \%$, and $3.32 \%$. According to these results, the highest percentage of alcohol (4.07\%) (Fig 4) was observed by $4 \%$ starch. However, the number of live cells in the medium started to decrease and number of dead cells increased after $36 \mathrm{hrs}$ (Fig 4). Therefore, alcohol production was optimized with culture parameters for $4 \%$ starch.

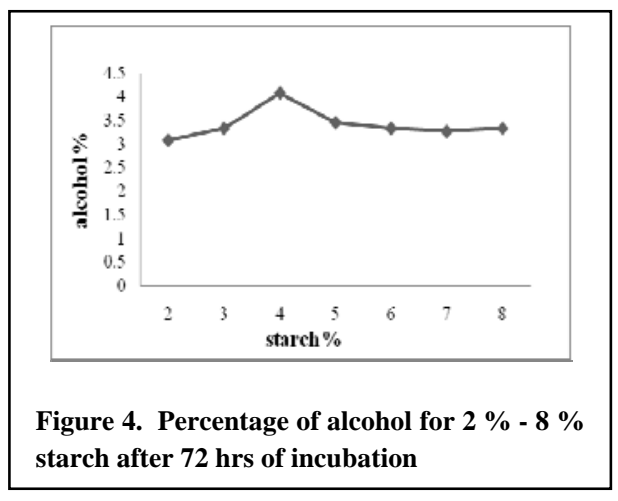

\section{Optimized Culture Conditions for Alcohol Production with 4\% starch}

The samples with $4 \%$ cassava starch showed maximum number of live yeast cells after $48 \mathrm{hrs}$ and then gradually decreased. This may be due to the increase percentage of alcohol in medium. The highest alcohol percentage of 2.5 was observed at 60 hrs (Fig 5).

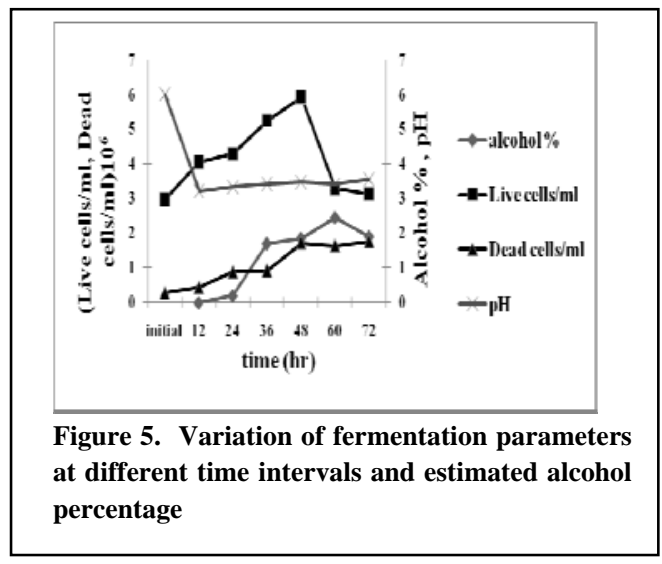

The results of different concentrations of enzyme for brix value optimization, $50 \%$ ammonium sulphate concentrated enzyme showed higher activity compared to crude samples and direct inoculation method. Maximum production of alcohol (3.6\%) was obtained under 50\% Ammonium Sulphate fraction treated with $3 \mathrm{~g}$ of cassava at room temperature. These preliminary results indicate that the enzyme has higher activity at room temperature. Thus with improve stabilization conditions, this enzyme has the potential to digest raw starch to yield fermentable sugars cutting down the cost of energy in the gelatinization step in conventional fermentation process. Results of the experiment conducted to optimize starch content to produce maximum brix value indicate that a brix value of 2.3 could be obtained with $50 \%$ ammonium sulphate fractionation after $12 \mathrm{hrs}$ incubation with $4 \%$ starch. The highest alcohol percentage of 4.07 was obtained with $4 \%$ raw cassava starch at RT. Further research should be conducted with this fraction of the enzyme adjusting for different concentrations, changing $\mathrm{pH}$ value to increase the activity of the enzyme to obtain a brix value of 10 which is the standard required value for fermentation.

\section{ACKNOWLEDGEMENT}

The authors wish to thank all the laboratory staff of the Department of Biotechnology Faculty of Agriculture and Plantation Management, Wayamba University of Sri Lanka for their great support. Mr. D.L.D. Jayantha General Manager, Mr. K. M. C. U. Senaratna, System Engineer, Pelwatte Sugar 


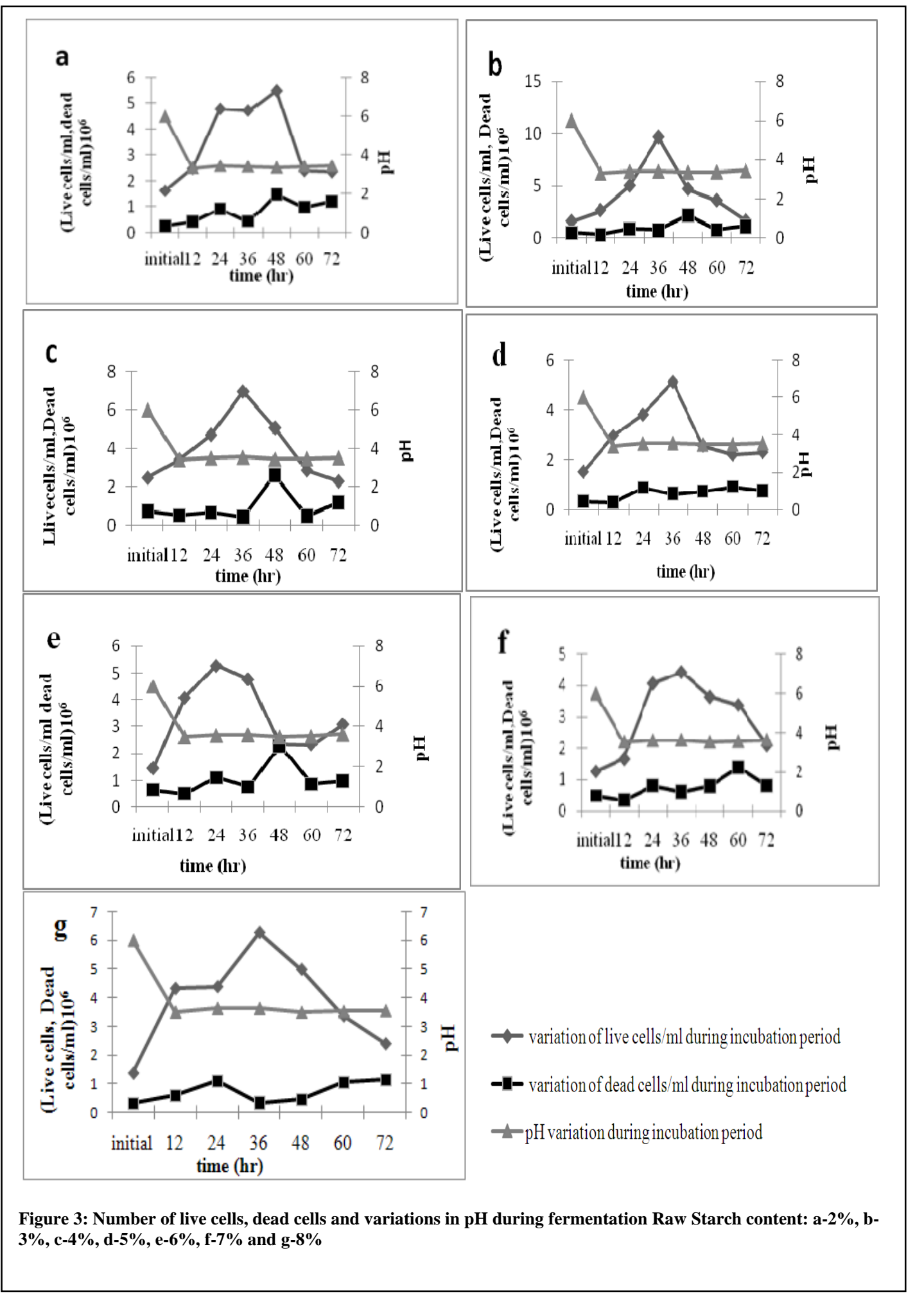


Distilleries Pvt. Ltd. Buttala and Dr. DilrukshiWijeratne, Department of Chemistry, University of Colombo for their cooperation given us to conduct this study. We also would like to acknowledge Dr. Ms. C. Yalegama, senior research officer Coconut Processing Research Division, Mr.J.M.M.A., Jayasundera, (Research officer) and other members in Coconut processing Research Division, Dr.L.K.Weerakoon, (Head of the division) tissue culture division, CRI. Lunuwila.

\section{REFERANCES}

[1] T.S.Khaw, Y. Katakura, C. Moukamnerd, A. Kondo, M. Ueda, and S. Shioya,"Enhancement of Ethanol Production by Promoting Surface Contact between Starch Granules and Arming Yeast in Direct Ethanol Fermentation". Journal of Bioscience and Bioengineering 103, pp95-97, 2007.

[2] M. Altintas, O. Kutulu, Ulgen., Z. BetulKirdar, L. Onsan, G.O. Stephen" Improvement of Ethanol Production from Starch by Recombinant Yeast through Manipulation of Environmental factors". Journal of Enzyme and Microbial Technology31,pp640-647, 2001.

[3] K.T. Seong, Y. Katakura, K. Ninomiya, Y. Bito, S.Katahira, A. Kondo, M. Ueda, S. Shioya, " Effect of flocculation on performance of arming yeast in direct ethanol fermentation". Journal of Microbial Biotechnology73, pp60-66, 2006.

[4] N.K. Aggarwal, P. Nigam, D. Singh,B.S.Yadev. "Process Optimization for the production of sugar for the bioethanol industry from tapioca, a nonconventional source of starch"World Journal of Microbiology \& Biotechnology17, pp783-787, 2001

[5] T. Osunsami, J.O.Akingbala, G.B.Oguntimein, "Effect of Storage on Starch Content and Modification of Cassava Starch" Journal of Starch41, 54-57, 2006.

[6] J. Abe, F.W. Bergmann, K. Obeta, and S. Hizukuri, "Production of the raw starch digesting amylase of Aspergillusspp, K-27"Journal of Applied Microbial Biotechnology.27, 447-450, 1988.

[7] B.N. Okolo, L.I. Ezeogu, and C.L. Mba, "Production of raw starch digesting amylase by Aspergillusnigergrown on native starch source" Journal of Science Food and Agriculture. 69, 109-115, 1995.

[8] S.N.T De Silva, D.P.S.T.G.Attanayake, S.F. Nirosha, and A.M.W.S.Aththanayake, "Isolation of row starch Hydrolyzing fungi and purification of alpha amylase from Geotrichumcandidum CMSS06"Journal of the National Science Foundation of Sri Lanka. 37 (2), 9398, 2009

[9] E.R. Jansz, N.Pieris, E.E.Jeyaraj, and D.J. Abeyratne, "A process for improved manioc chips and flour, $3^{\text {rd }}$ ed.industrial microbiology section, Ceylon institute of scientific and industrial research",pp3-5, 1976.

[10] Chaplin and J.F.Kennedy, "Carbohydrate Analysis a practical approach". pp11-55, 1986.

[11] S.N.T De Silva, "Purification and characterization of Raw Starch Hydrolyzing $\alpha$-amylase from Aspergillusspp RSH I \& RSH II, Unpublished M.S.c thesis, Faculty of Medicine, University of Colombo, Sri Lanka", 1997.

[12] S.P. Colowick, N.O. Kaplan, E.F.Neufeld, and M.M.Ciotti, "Pyridine nucleotide transhydrogena.InInderectevidenfor the reactionand purification of the enzyme, Journal of Biological Chemistry. Mar ,195(1), 95-105, 1952.

[13] Anon. (2010 a). Refractometry. Available http://www2.ups.edu/faculty /hanson/ labtechniques/refractometry /mailto (Accessed April 16 2010).

[14] Anon. (2010 b). Yeast Viability Measurements in Fermentation Studies, Available:http://fluidimaging. Com /fluid Imaging Technologies, (Accessed May 12, 2010).

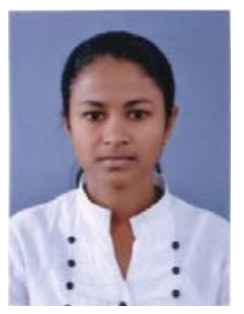

Ms. M.MW.K.B. Manchanayake is a recent graduate in Agriculture specialized in biotechnology at the department of biotechnology, Wayamba University of Sri Lanka. She is currently attached to the Hector Kobbekaduwa Agrarian and Research Institute

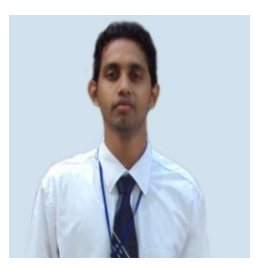

Mr.A.J.A.Tilakaratna is reading for his Masters in Experimental Biotechnology at post graduate institute of science at University of Peradeniya, Sri Lanka and graduate in Agriculture specialized in biotechnology at the department of biotechnology, Wayamba University of Sri Lanka.

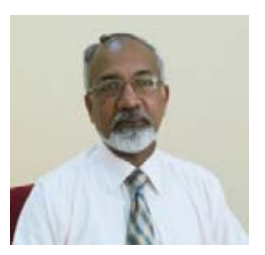

D.P.S.T.G Attanayaka serves as an Associate Professor in Biotechnology, Faculty of Agriculture and Plantation Management, Wayamba University of Sri Lanka. He is currently working as the Dean of the Faculty. His research interests are on genomic organization and expression of

the genes involved in Rubber biosynthesis in Heveabrasiliensis and genetic improvement of cashew using traditional and biotechnological methods. He is also involved in research and developmenent of industrial enzymes. He has supervised five postgraduate research students and fourteen publications to his credit in peer reviewed journals

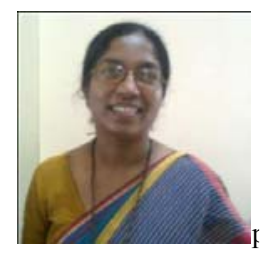

Dr. S.N.T. De Silva is currently working as a senior lecturer at the Department of Biotechnology, Wayamba University of Sri Lanka. She has extensive experience in protein chemistry and enzyme are on industrial enzymes, renewable energy and waste management. 